\title{
On Semantic Equivalence, In Translations of the Book of Proverbs: A Case Study
}

\author{
Anahit Hovhannisyan ${ }^{1}$ \\ ${ }^{1}$ M. Nalbandyan State University of Shirak Foundation, Armenia \\ Correspondence: Anahit Hovhannisyan, 4 Building, Paruyr Sevaki St., Gyumri, Shirak Region, 3126, Armenia.
}

Received: July 26, 2021

Accepted: August 23, $2021 \quad$ Online Published: September 3, 2021

doi:10.5430/wjel.v11n2p127

URL: https://doi.org/10.5430/wjel.v11n2p127

\begin{abstract}
The topic of this paper covers one of the mysterious and fascinating topics of biblical study, specifically biblical proverbs. The paper is primarily devoted to outlining translation equivalents of semantic parallelism across two languages - English and Armenian. By employing the method of comparing cultural values, are outlined the architecture of semantic parallelism and the role of translator as an agent of cultural mediation in regard to translation of biblical proverbs.
\end{abstract}

Keywords: biblical proverbs, semantic parallelism, contrastive study, synonymous parallelism, synthetic parallelism

\section{Introduction}

Nowadays there is a revival of interest in religion and particularly in the Bible as an authoritative source which defines the spiritual life of a man for all eternity. This book is one of the richest and inexhaustible sources of outstanding proverbs. Originating in ancient times, biblical proverbs have accompanied people in their immemorial existence, enriching and enhancing their imaginative thinking as well as the national language. In fact, various aspects of life - social experience, mental, ethical and aesthetic values, and social ideals — are manifested in biblical proverbs. They most clearly illustrate the lifestyle, history and traditions of a community united by a single religion and culture. Therefore, studying biblical proverbs in English and Armenian is remarkable not only on the basis of linguistic significance - as they form an integral part of the world literary heritage — but also on the basis of discovering the language habits, religion and culture behind the contrasted languages.

\section{Methodology}

Theoretical background is based on cognitive approach to study of proverbs proposed by R. Honeck (Honeck:1997) and is also anchored on comparative methodology of translation on comparative methodology of translation for comparative study of stylistics (Vinay and Darbelnet:1995).

The contrastive study of semantic parallelism as a rhetorical device performed within a biblical context helps us to determine their universality on the one hand and to reveal their different semantic and structural characteristics on the other hand.

\section{A General Overview of Biblical Proverb}

A biblical proverb is defined as "a short saying that expresses a general truth for a practical and godly living." The fundamental truths of life are illustrated through comparisons in the book of Proverbs. Actually, the word "proverb" means "to be like". The aim of proverbs is to pass on wisdom in a terse and memorable way. This creates a contradiction of simplicity, yet profundity. The Bible delineates proverbs as "sayings of the wise" (Proverbs 24:23). The biblical Book of Proverbs should be interpreted differently from other parts of the Bible since it is the Bible's wisdom literature and must not be read literally.

Proverbs are separable units planned or conceived for conversational reattachment in new situations. The importance of proverbial usage is distinctly acknowledged in the biblical Book of Proverbs itself: "Like a lame man's legs that hang limp is a proverb in the mouth of a fool" (Proverbs 26:7,9).

Modern studies have indicated that proverbs are spoken usually by elders and rarely by the young. Honeck, from a cognitive perspective, notes that proverb usage among children below the age of 10 is unheard of largely because citing a proverb is an indirect way of accomplishing social goals (Honeck, 1997: p. 262). The linguist Norrick 
observes that older speakers usually use proverbs when speaking authoritatively with an instructive and sententious purpose (Norrick, 1985: p. 149).

Modern scholars trained in the theoretical aspects of speech acts now look at proverbs as part of active verbal communication. It is definitely true that with the appearance of discourse, pragmatics and conversation analysis, attention has turned to the function of proverbs in text and it has seemed obvious that proverbs can be identified with certain speech acts. The contemporary use of the speech acts goes back to J. L. Austin's development of the theory of locutionary, illocutionary, and perlocutionary acts. With the new developments in phraseology, it was recognized that not only should the content of the used proverb be understood (the illocutionary act) but also the actual impact of the statement on the listener should be carefully noted (the perlocutionary act). An illocutionary act is a way of using language, and its performance is the performance of an act in saying something as opposed to the performance of an act of saying something. It corresponds to the force that an utterance has in a particular context: order, request, entreaty, or challenge. The perlocutionary act corresponds to the effects brought about by performing an illocutionary act, to its consequences (intentional or non-intentional) on the feelings, thoughts, or actions of the participants. For, example, the perlocutionary effect of some proverbs may be a rebuke, disapproval, warning, encouragement, or even humor depending on who the speaker is and to whom it was addressed (parents to a child, grandparent to grandchildren or scion parent, wife to a husband or vice versa) (Austin, 1975: pp. 117-120).

A proverb may be used to highlight ideals that are either confirmed or dis-confirmed (Honeck, 1997: p. 144). Proverbs 10:1, as typical of many antithetic proverbs, gives both the ideals-confirming (wise son/joy to father) and the ideals dis-confirming (foolish son/grief to mother) sides, thereby doubling the intended impact by using both approach and avoidance a motivational strategies in a single saying.

Culture also plays a significant role in determining how a proverb is to be understood. Researchers from different fields of knowledge claim that culture is reflected in the minds of people and it determines the specifics of their understanding. National features of communicative behaviour that we encounter in communication is the collective habits of the people. Thereby, norms of understanding and communication differ markedly from each other in the variety of cultures that our world is inhabited by. So it is natural that proverbs are also interpreted differently by people of different cultures and nationalities.

It should be taken into consideration that the originality of the language picture is shaped by categories of reality and it depends on the figurativeness of the language, in which world-view, world perception, and the way of living of a particular nation are reflected. Proverbs represent a substantial source of information, especially for linguo-cultural investigations being a unique means of cognition and interpretation of culture, mentality of language representatives. Therefore, proverbs are an integral part of the spiritual treasures of the language and culture of the people.

Being a comparatively recent branch of paremiology, the contrastive study of proverbs makes even greater use of the concepts that have already become common among proverb scholars, such as proverb classification, translation, meaning (sense)/interpretation, semantic equivalence, semantic analogy, etc. Semantic equivalence is the deep equivalence in translation based on equivalences of format, rhythm, grammar, part of speech, etc. Semantic equivalence implies that the translation and the source text should achieve equivalent results in the expression. The hidden meanings in the source text should be reflected in the target text. For example, the feelings which the author conveys and the effect that the feelings have on readers can make the readers of the two languages achieve the same position when appreciating the texts of different languages. Semantic equivalence is to make languages produce the same feelings without borders. This kind of equivalence is particularly useful in translating idioms and proverbs (Linyan, 2017, p. 165).

Despite differences in various spheres of human activity, under which the nation of the source language and that of the target language develop, particular notions in both languages may be identical or similar in their meaning and functioning. The appearance of analogous units in the national layer of the vocabulary of different languages may also be the result of bilateral or multilateral influences to which the nations may have been exposed for centuries. Consequently, analogous national notions in different languages may appear as a result of direct or indirect borrowings (i.e. the SL word is transferred directly to the TL). Direct borrowings result in the formation of loan words, which undergo the phonological system of the borrowing language. Indirect borrowings typically occur through coinage where only the sense of the foreign term is taken, and not the word itself. It is no wonder that analogous units of national vocabulary directly correlate in the SL and TL in their denotative meaning and mostly in the common sphere of their functioning - social, cultural, etc. The connotative divergences and sometimes the spheres of use may not always fully coincide in the TL since the choice of the appropriate analogy is mainly influenced by the national/cultural traditions (Studfile.net). 
The book of Proverbs is written as poetry. It utilises many of the literary techniques common to Hebrew poetry vivid figurative language, parallelism, and other techniques - to guide the reader in the search for godly wisdom. The wisdom embodied within the Book of Proverbs overlays almost every aspect of life. The proverbs focus on the behavioral habits of humans and man's proper relationship to God as all-good and all-powerful.

To illustrate the difficulties inherent in the translation of proverbs, first of all, it is instructive to attempt to classify biblical proverbs. There is no generally accepted classification of biblical proverbs or sayings in the world. So the wise sayings and proverbs can be grouped in a number of ways. At a very general level, the proverbs can be described as statements of truth-"Kind words are like honey" (16:24); or as instructions- "Accept correction, and you will find life" (10:17). But the proverbs can also be described by the form or pattern they take. Semantics of proverbs is strongly intertwined with their architecture, specifically with parallelism.

One characteristic of Hebrew is captured well and appears in many proverbs. This characteristic, known as parallelism, refers to how Hebrew poetry rhymes with words rather than sounds. Parallelism denotes giving two (or more) parts of one or more sentences a similar form to make a definite pattern. Parallelism is a rhetorical device used in many languages and cultures in poetry, songs, epics, prose and oral speech. This device is often found in Biblical poetry, too, and particularly in proverbs. The greatest technique of biblical poetry is not to rhyme sounds, as in much English and Armenian poetry, but to "rhyme" ideas — that is, to put two or more lines together that somehow match each other. Parallelism is the cornerstone of biblical poetry since it can be translated properly into almost all languages and not too much beauty is actually lost in translation processes. The technique of parallelism is used throughout the book of Proverbs mainly to amplify meaning.

Parallelism works in two main ways: semantic and syntactic. The standard illustration of the parallel relationship between the two lines has been semantically designated as follows (Lowth, R., Isaiah, 1778: pp. 476-486):

\section{Semantic Parallelism and Its Conveyance in Armenian Translations}

1. Synonymous (tautological) parallelism, i.e., meaning repeated or similar parallel - As the name implies, the same instruction is given twice in similar ways. In other words, the second line expresses the same idea as the first one but in different word patterning. This type of parallelism is typically used to express a lesson of the proverb with maximum clarity and emphasis. The book of Proverbs contains multiple pairs of word synonyms:

- "Wisdom cries out in the street; in the squares she raises her voice."(Proverbs 1:20)

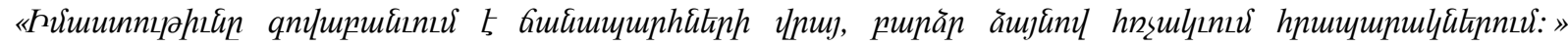
(Unulyakn 1:20)

Solomon states that wisdom is accessible to anyone who actually wants it. The voice of wisdom sounds everywhere - in public, in street, etc. The irony implies that very few people are inclined to hear her voice. In fact, everyone can, but not everyone will.

In this proverb, the parallel structure links the similar concepts "cry" and "raise one's voice." They are amplified in importance being placed next to each other. It is also noteworthy that the rhyming of this statement enhances the sentence with much more colouring due to the syntactic inversion in which the adverbial modifier of place ("in the squares") takes an initial position in relation to the subject "she." It is important to observe the inequivalence between the verb "cry" and its Armenian version. The artful choice of the verb "qnulupuntal" by the translator makes the Armenian sentence more emphatic, echoing the role and mission of "wisdom." But at the same time, the dynamic equivalence is quite well preserved. As for the next pair of parallels, in Armenian the verb "hn々̧ulltı" is added to strengthen and clarify the idea. This verse portrays an image of wisdom, personified as a woman, crying out in the street. But, of course, this differentiation is not visible in Armenian translation because of the lack of gender modification in the system of personal pronouns in the mother tongue. Instead of personification, in the Armenian translation, preference is given to the passive voice. The passive voice is used to show that the process or principle being described is of ultimate importance as opposed to the performer of the action (it is obvious that this case of passive implies human activity).

- "My child, do not despise the Lord's discipline or be weary of his reproof." (Proverbs 3:11)

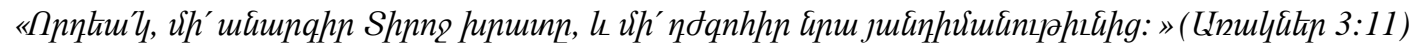

In this verse, the verb "to despise" operates as a contextual synonym to the verb "to be weary" (or "to resent" in some other translations). The word "uumunqti" in Armenian translation functions as a complete equivalent since it unleashes the meaning of the English word "despise": to have no respect for somebody/something, to regard with contempt, worthless or negligible (Oxford Advanced Learner's Dictionary, 2005: p. 415). In terms of equivalency 
the verb "ndqnhtil" does render the meaning of the English word "to be weary": to become impatient or dissatisfied after doing something for a long time (Oxford Advanced Learner's Dictionary, 2005: p.1728), but not completely. Nevertheless, they have the same stylistic value and play the same impact on target readers. Analogically function the nouns "discipline" and "reproof" with their Armenian equivalents "hupuu" (in some cases "uyuunh") and

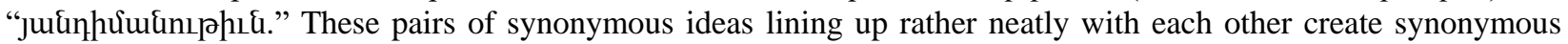
parallelism. They serve to emphasize the performative act of the speaker's speech.

- "A generous person will be enriched, and one who gives water will get water." (Proverbs 11:25)

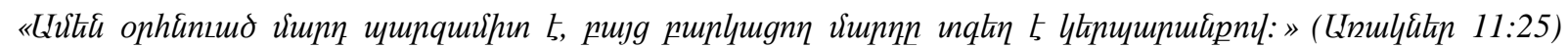
(non-equivalence)

The proverb is shaped as two parallel statements. The first statement is general: a generous person will be enriched. The second statement echoes the meaning of the first one, but demonstrating another patterning: one who gives water will himself get water.

Vinay and Darbelnet (1995: p. 342) believe that target language equivalents should "replicate the same situation as in the original, whilst using completely different wording." The word translated into English as "generous" in Hebrew implies the meaning "ophunıud" used in Armenian version. This synonymous parallelism is translated into Armenian as an antithetic parallelism. It is noteworthy to observe that several other Armenian translation versions

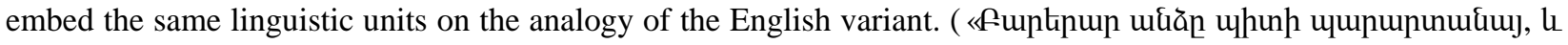
nnnqnпр` h'\{p ul uhunh nnnqnıh:»).

The proverb draws a picture of the reciprocal nature of actions: you will taste the results of your nowadays' behaviour in the future. The sense of this proverb finds its equivalence in another biblical saying:

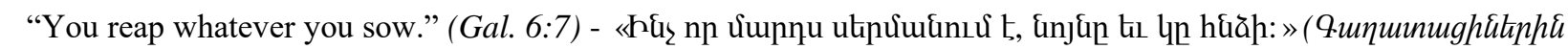
6:7)

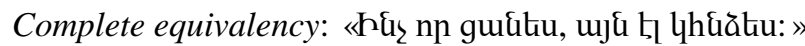

Many similar statements can be found in everyday speech of Armenians:

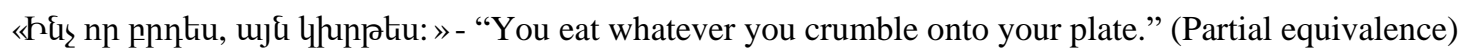

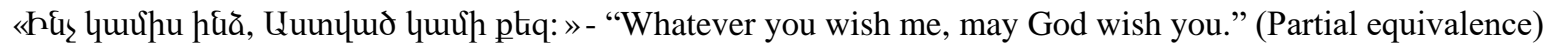

- "Those who trouble their households will inherit wind, and the fool will be servant to the wise." (Proverbs 11:29)

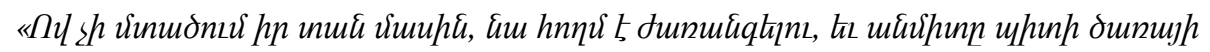

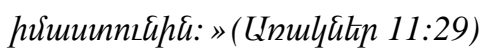

The verb "trouble" here means "to disturb, to stir up, or to bring calamity" (Oxford Advanced Learner's Dictionary, 2005: p. 1642). One can trouble his/her own house by being a constant source of conflict within it. But other things can also trouble a house. Anyone guilty of disobedience to God, selfishness, carelessness, or cruelty - will bring serious problems to the family. It is well known that a home can be a peaceful place to live - or a torturous one. This is a clear picture of an empty inheritance at the end of life. The second part of the proverb also warns us that the foolish will eventually be a servant to the wise-hearted. Someone wise in heart will certainly be the one in charge. English and Armenian translations almost match each other representing a case of dynamic equivalence.

The below-adduced proverbs find their dynamic equivalence in the target language, representing faithfulness to textual meaning and its effects:

- "Pride goes before destruction, and a haughty spirit before a fall." (Proverbs 16:18)

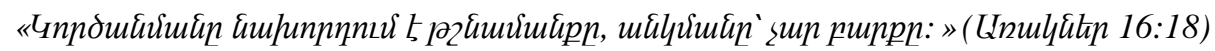

An inversion operates in the Armenian translation, making word-arrangement much closer and comprehensible for target readers.

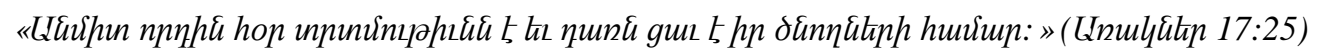

Modulation in the above translation (children - nnnh) yields to rhyming. That is so specific for proverbial composition. 
2. Antithetic Parallelism, i.e., meaning contrasted or opposite parallel - The second line or statement is given twice but in opposite ways (it contrasts with the first one and usually by means of the adversative conjunction "but"). This is the most common structuring in Proverbs:

- "A wise child makes a glad father, but a foolish child is a mother's grief." (Proverbs 10:1)

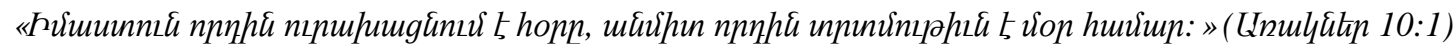

In this translation, as in the above verse (Proverbs 17:25), the technique of modulation is applied (child - nnnh). The coded message is the same, but the wording used in English and Armenian is different. The emergence of the noun "nnnh" in Armenian translation is of great significance. This word of address has acquired a value of term over time. In ancient times it was mainly used as a word of neutral gender implying both masculine and feminine genders (son/daughter). This tradition passed on from generation to generation; so this approach is still relevant and is commonly used throughout the Bible. The word "nnnh" became a term in the 5th century; beyond contextual usage, it means "son" (2.someone who replaces the son, 3. descendants, generation). It is astoundingly interesting that the

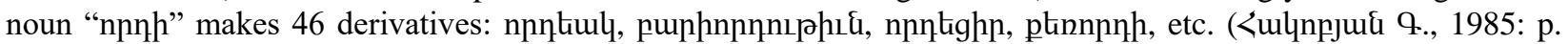
74). This word (with its derivative "nnntiul") is found in the Bible for more than 3000 times. The importance of modulation in the translation lies in the fact that it endues naturalness on the TL sentence so that the reader is illuded by the feeling that he/she is not reading a translation, but an original text.

Antithesis, used in the above proverb, brings out a contrast in the ideas by an opposition between the phrases "a wise child" and "a foolish child." Are of equal interest Hebrew equivalents of the adjectives "wise" and "foolish." The adjective "wise" here stands for the Hebrew word "hakham" (Audioenglish.org). It means "to be experienced in something; skillful." The book of Proverbs begins with the following statement: "the fear of the Lord is the beginning of wisdom." This is what the claim implies. The adjective for "foolish" is "kesil," meaning "a stupid, fool, or dull person" (Bible Hub). A person becomes foolish when he does not live a godly life. The other contrast reveals the child's behaviour towards his parents. The contrast here is the way the mother's heart is broken when her child begins to adopt an indecent life. Of course, the vital role of parents in the life of a child is of universal nature but it would not be an exaggeration to say that among Armenians, parents are worshiped.

Similar variations of the above-mentioned proverb can be found throughout the book of Proverbs:

$>\quad$ "A wise child makes a glad father, but the foolish despise their mothers." (Proverbs 15:20)

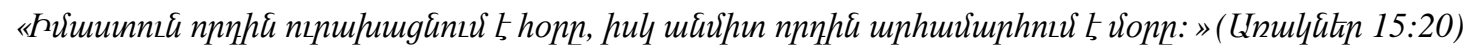

$>\quad$ "Foolish children are a grief to their father and bitterness to her who bore them." (Proverbs 17:25)

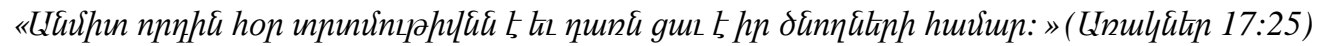

$>\quad$ "My child, if your heart is wise, my heart too will be glad." (Proverbs 23:15)

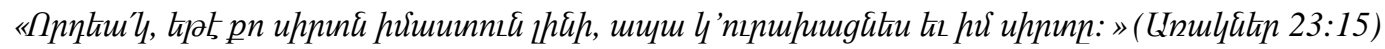

$>\quad$ "The father of the righteous will greatly rejoice; he who begets a wise son will be glad in him." (Proverbs 23: 24$)$

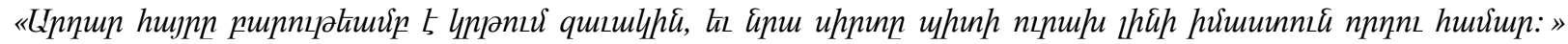
(Lnwliktn 23: 24)

Are of equal interest conjunctions "but, and" with their counterparts in the mother tongue, which best express the contrast between the two phenomena.

- "A cheerful heart is a good medicine, but a downcast spirit dries up the bones." (Proverbs 17:22)

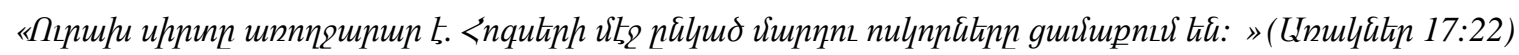

This device, putting two lines "against" each other, forms a contrast and encodes the message - what happens when one chooses a path over the other. Joy and happiness have a healing effect on people. The adjective "cheerful" here stands for the Hebrew word "sameach" which means "to be glad or joyful" (Biblestudytools.com). Thus, both in English and Armenian languages equivalents convey the original idea (cheerful-nıpulu). The concepts "heart" and "spirit" could be interchangeable here. The human heart, invisible to sight, is used to symbolise the emotional and spiritual life and the centre of self-consciousness. The expression "a downcast spirit" is paraphrased in Armenian; a similar meaning finds dissimilar pattering. It is noteworthy that an adage of this verse is commonly used in Armenian

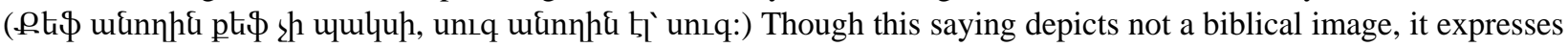


an idea conceptualizing biblical ideology. The message of this proverb is unleashed in another biblical proverb patterned as an antithetic parallelism:

"A tranquil mind gives life to the flesh, but passion makes the bones rot." (Proverbs 14:30)

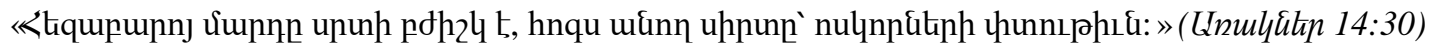

- "When words are many, transgression is not lacking, but the prudent are restrained in speech." (Proverbs 10:19)

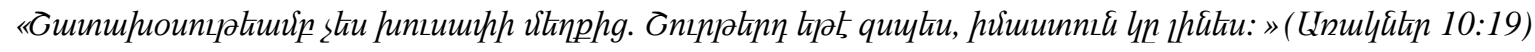

The translation illustrates a well-known concept in translation studies - paraphrasing. Applying this strategy, translators have produced an alternative version of translation by changing the wording of the target sentence. Paraphrase is useful and handy because it helps the reader in understanding the theme of the proverb. It should be noted that this technique also effectively contributes to overcoming the problems occurring during the translation process, specifically cultural items.

- "The wicked flee when no one pursues, but the righteous are as bold as a lion." (Proverbs 28:1)

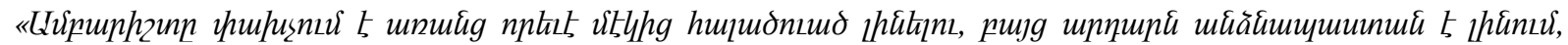
hüuku шиhıd:» (Unulikthn 28:1)

English and Armenian translations above have a similar meaning but different lexical compositions. In the Armenian version, translators tried to enhance the expression with some wisdom aesthetics by replacing the propositional meaning of the word "bold" with its expressive conveyance "ufű̊uuuuuuunuf." Paraphrasing (when no one pursues

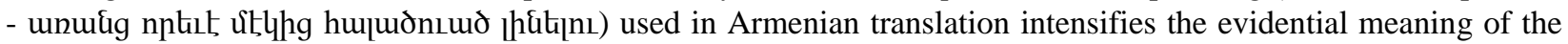
proverb accentuating the whole message.

The message of the proverb becomes more impressive and colourful due to the technique of simile (as bold as a lion

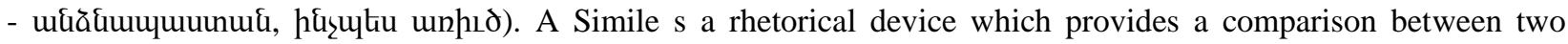
completely different objects. The translation of similes sometimes is difficult and tricky, posing many different troubles if the translator is not aware of the cultural differences between the two languages. But in this case, the translators had no difficulty in transferring the meaning to the target language readers, since the given simile has found its equivalent in many languages, including English and Armenian.

The proverb is a powerful confirmation of the truth that the wicked are easily intimidated. They fear even mere shadows. The righteous are like the fearless lion (Proverb 30:30). The conscience of the righteous is made clean by the righteousness and decency of God imputed to them through faith.

3. Synthetic Parallelism - The third literary form is described as synthetic parallelism, in which the second line not merely intensifies the thought of the first but actually supplies additional information. Thereby this type of parallelism is characterized by advancing, completing, or developing thought. This is different from synonymous parallelism, which amplifies a thought with synonymous repetition without providing further clarification or an extension of the first line.

Synthetic parallelism can be divided into several smaller subcategories:

3.1. The first type of synthetic parallelism is not actually parallelisms at all. Its only function seems to be to delimit a class or certain behaviors/traits. These proverbs are typically single statements describing some truth. They are often short, bold statements or simple warnings usually comprising a single sentence and embracing the verb "to be" in its conjugated forms.

- "Do not give what is holy to dogs; and do not throw your pearls before swine." (Mt 7:6)

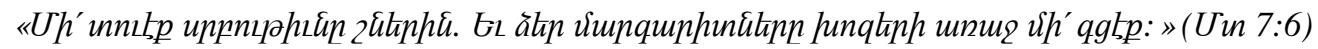

This proverb functions as a warning in both languages. It sounds like a proverb as it is short and concise. Translated versions represent a case of partial equivalence, and the pragmatic function of each word is rendered accurately.

Animals have a key place in the Bible, some appear frequently and their role is significant for a better understanding of the whole biblical message. Some animals symbolise wealth, kindness and obedience, while others occupy a strikingly contrasting, neglected position, like the dog. Pigs were ritually unclean, but dogs were the embodiment of gluttony, scavengers sent by God to rip apart and devour. Metaphorically speaking, the dog personifies dirty, filthy and worthless habits. 
It is noteworthy that both in English and Armenian there is a wide range of phrases and sayings that bring dogs into the human world, as symbols of human characteristics or conditions. When life is hard, both English and Armenian

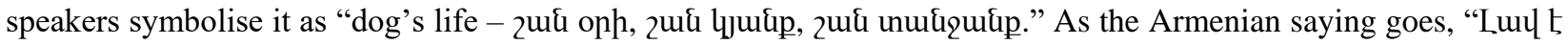

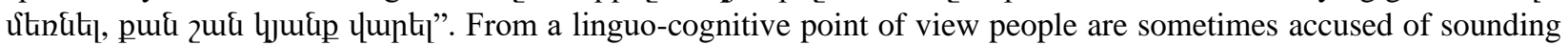
like dogs - "to bark - utter (a command or question) abruptly or aggressively." In Armenian it also implies a slightly different shade of meaning: "2wu ulku huzkl - 1.to talk nonsense, 2. to express sharp but pointless disapproval or criticism, 3. to curse" (Unujuú E., 1976, t,2 826).

In Armenian there are other sayings referring to wasted goodness - a person, worthy status or wealth - lost without good use:

«Gikinng hifitl» - To become a belonging of dogs (in regard to goodness or wealth wasted)

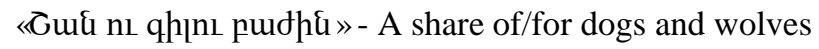

These are fixed phrases used by the representatives of Armenian language and culture with conventional meaning like proverbs but they differ from proverbs in terms of incompleteness and dependence on the context.

All this is different from the current perception of the dog as the most popular pet and "man's best friend."

- "Haughty eyes and a proud heart- the lamp of the wicked - are sin." (Proverbs 21:4)

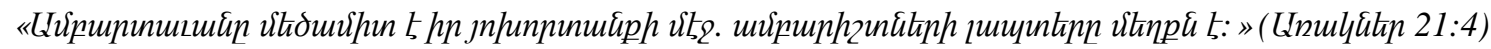

The first part of the given proverb is paraphrased in Armenian but it still has the same pragmatic value as the English version. The word "haughty" is always used in the Bible in the evil sense of "arrogant, pompous and setting oneself above others"; it is often set in contrast to being modest and humble. The phrases "haughty eyes" and "a proud heart" are rendered into Armenian by a word with a more generalized meaning (uupupunuluน). Generalization is resorted here for pragmatic reasons.

Pride is depicted as a lamp that lights or guides the way of wicked into sin. In his poem, The Divine Comedy, Dante Alighieri listed pride among the seven great deadly sins. Moreover, it takes the first place on the list as it is considered to be the father of the rest six sins.

3.2. The next structure of synthetic parallelism presents actions side by side. Proverbs that formulate an argument from lesser to greater are easy to recognize, for they have the mould "how much more" in the second line:

- "Sheol and Abaddon lie open before the Lord, how much more human hearts!" (Proverbs 15:11)

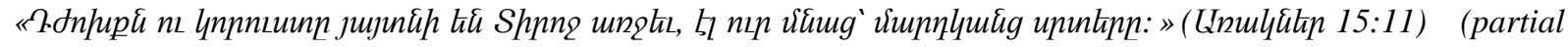
equivalence)

In this proverb the first two phenomena (Sheol and Abaddon - ndnhupu nı lnnnıunn) are compared to the second one (human hearts - umpnlyuig unutinn), which is of greater consequence. This verse contains two original Hebrew

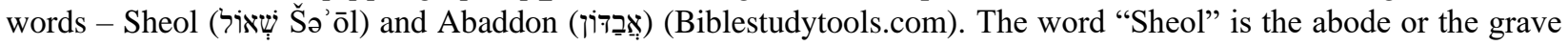
of the dead (Uthnud ufaătinn luujud) in early Hebrew thought. "Sheol" was also believed to be a place of darkness, dust, and silence to which the spirit descends at death. However, some linguists claim that in the Hebrew Bible it refers to an underworld deity responsible for ruling the abode of the dead. Despite these arguments, one thing is certain - English has borrowed this word from Hebrew. Even though this loanword is also used in Armenian ( $2 \mathrm{kn} p$ ), in the given verse it is replaced by its contextual synonym "ndnhup - hell." Actually, "ndnhup" is a Persian borrowing but in Armenian it is on a par with the native Armenian words.

The same can be said about the second word "Abaddon - Upunnn£" where perfectly works transliteration. It is a Hebrew word commonly used in the Bible regarding a bottomless pit/an underworld abode of lost souls. Hence, abaddon is related to "loss, deprivation - lnpnıuun."

In fact, "Sheol" and "Abaddon" are words implying much more general meaning, and in Armenian they underwent narrowing of meaning, being rendered as concrete nouns; a process dictated by the social context.

As for the key phrase of this proverb "how much more," it is translated with an equivalent local phrase "Һц nıp ufuug" which conveys the same meaning. It can be said that they are equivalents at the phrase level. An emphasis should also be given to the pragmatic aspect of equivalence. In some Armenian translations "how much more" is rendered literally "nnцuщ uцltih." However, the literal translation could hardly convey any sense to the Armenian receptor for whom the encoded meaning is intended. In this case, the pragmatic aspect motivated the translators to choose a more acceptable phrase for the target reader. 
- "The sacrifice of the wicked is an abomination; how much more when brought with evil intent." (Proverbs 21:27)

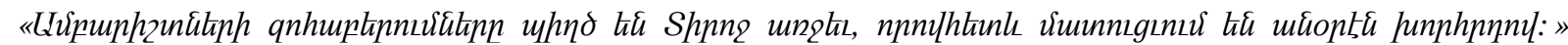
(Lnuluitin 21:27)

The couplet begins by stating a sinful action — offering a sacrifice with a wicked heart - and then it gives that action more energy by comparing it with an even greater sin - offering the sacrifice for the special intention of sinning. In other words, when holiness is pretended, but evilness intended, that especially is detestable.

Reference should be made to the fact that English and Armenian translations hardly coincide with regard to form and meaning. The noun "abomination" in English is replaced by the adjective "uhnd" in Armenian, i.e. A substitution of part of speech method is applied to render the meaning of disgust and obscenity.

It can be noted that English verse contains implicit information which is rendered explicitly in Armenian. This procedure supposes an addition of extra words (Shnn 2 ungtil) to clarify the meaning for the receptor.

The next non-equivalents are the phrase "how much more" in English and the conjunction "npnlhtinl" in Armenian. This kind of replacement has altered the original meaning of the proverb. It's an argument from "less than" to "greater than" which being preserved in English is lost in Armenian. The conjunction "nnnlhtiul - because"

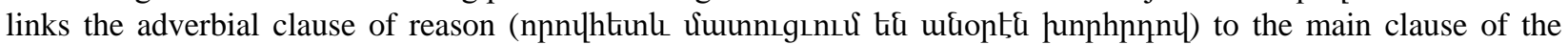

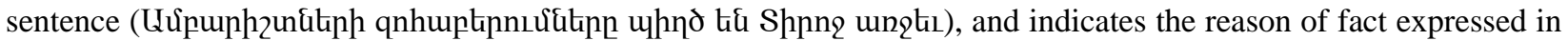
the main clause rather than presents an action of a greater consequence. Thus, translators have failed to have the same meaning and effectiveness of the given proverb in Armenian. The phrase "how much more" could be

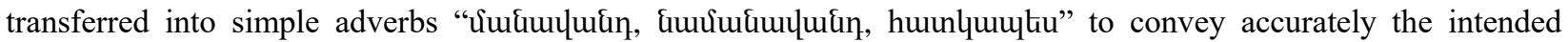
message.

3.3. Statements/Consequence - In some synthetic parallelisms the first part makes a statement of the second one to express some consequence. In other words, the second line explains the consequences of doing or not doing something. These are typical "If...then" statements and "or else" instructions. The "or-else" formula is usually implied but not stated.

- "If you have found honey, eat only enough for you, or else, having too much, you will vomit it." (Proverbs 25:16)

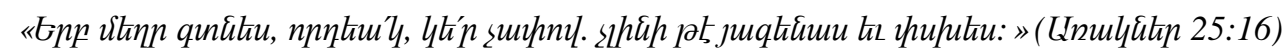

English and Armenian translations convey the same meaning expressed by similar images. In the Armenian version "if" conjunction is replaced by "tipp - when." It is also remarkable that the phrase "or else" which conveys a meaning of consequence is substituted by the adverbial phrase "yh氏 pl" which in this context functions as a subordinating conjunction. Apart from this, the strategy of modulation (cause-effect) is used to transfer the meaning of "having too much."

The theme of responsibility for actions can also be observed in Armenian proverbs:

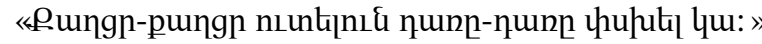

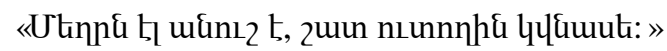

All these proverbs lead to the theme of condemning excessive behaviour; as the Armenian saying goes: «Lutiu huc

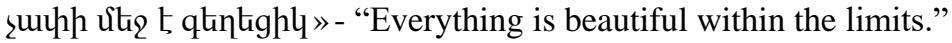

Even the "symbol" of prosperity, the honey, may turn into the cause of affliction if it is disproportionate.

3.4. Statements/Basis - This type of synthetic parallelism functions in an absolutely opposite manner in relation to statements/consequence formula. In the statement/basis parallelism, the first line makes a particular statement, and the second line provides the basis for that statement. The second line in some way confirms the first line. In English versions some parallelisms of this type can be easily recognized by the conjunction "for" which introduces the second line of the proverb, as in Ecclesiastes 11:1:

- "Send out your bread upon the waters, for after many days you will get it back." (Eccl 11:1)

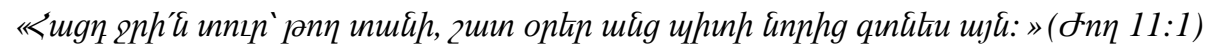

There is a decoded rendering in the Armenian translation (pnn unuin). The addition of this phrase in Armenian version is of pragmatic value. The conjunction "for" which in the English version has a distinctive role, is omitted in the Armenian translation. The meaning of the conjunction is implied without any concretization, thus "for" can safely be left out. 
Rather close synonyms to the given proverb circulate in everyday speech of Armenians:

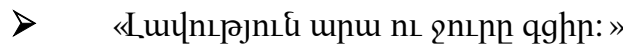

"Do goodness and throw it into the water."

This is almost a complete match with the above-adduced biblical proverb. Thus, these proverbs can be considered equivalents in meaning.

A clear antonym to the two proverbs above is the following one:

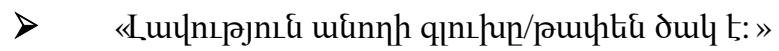

"The benefactor is an airhead."

It expresses a view opposite to the biblical ideology (opposite mentality) but has distinguishable similarity in the wording.

4. Numerical parallelism - This is a common means of expression composed of numbers and other words with numerical meanings. Some proverbs comprise images that compare one thing/person to another. Proverbs 17:10 is a good example of numerical parallelism in which the phenomenon of the first line stands in comparison to the second one, specifically the indefinite article "a" implying "one" in the word "a rebuke" stands in opposition to the word "a hundred":

- "A rebuke strikes deeper into a discerning person, than a hundred blows into a fool." (Proverbs 17:10)

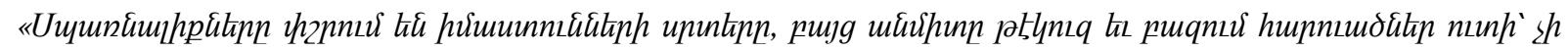
mqqıмиर:» (Lnullatin 17:10) (dynamic equivalence)

The Armenian translation of the verse perfectly reveals the nature of paraphrasing; the content of the utterance is rendered by different grammatical and semantic units, for all kinds of lexical and grammatical transformations could hardly be applied effectively. It is striking that the numeral "hundred" in the English version is translated in terms of its implied meaning - "puqnuu." It is common knowledge that numbers in sayings, proverbs or idioms of a particular nation carry certain cultural elements or connotations. The mentality has a significant effect on the perception of different numbers. The key fact here is that both in English and Armenian proverbs numerals "hundred" and "thousand" have the figurative meaning of "many, numerous." As a rule, they are used in an opposition to a small quantity or "one", but not necessarily:

"A picture is worth a thousand words."

Moreover, an example of such Armenian proverb-opposition of "one versus thousand" somehow matches the above-adduced proverb:

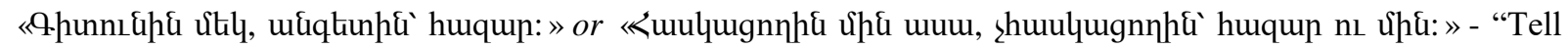
once the wise, and a thousand times the fool."

The Armenian proverb has a wider meaning; however, both the meaning and the form are moulded in accord with the biblical passage (Proverbs 17:10).

5. Emblematic parallelism - The final type of semantic parallelism we are going to discuss occurs when the proverb pictures some truth or gives an emblem/symbol or an illustration clarifying that truth. In other words, the verse that exhibits emblematic parallelism features metaphor and its interpretation - an extended simile/comparison, enhancement of a meaning or a pearl of ancient wisdom.

Proverbs 17:8 is a vivid example of the use of emblematic parallelism:

- "A bribe is like a magic stone in the eyes of those who give it; wherever they turn they prosper." (Proverbs 17:8)

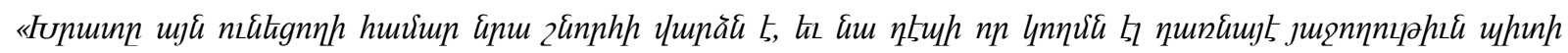
qunih:» (Lnulukitn 17:8)

The emblem in this proverb is "a magic stone," symbolising "kindness, favor." This verse can lead to misconceptions both in English and Armenian versions; they are neither moulded relevantly in the contrasted languages nor implying the same message. There is therefore a need to look more deeply into the translations of the proverb and to find original Hebrew words related to the source biblical passage for bringing more clarity and shedding light on the meaning of the verse. "Bribe" in the Hebrew language is "shachad" which literally means "gift, present" (Blue Letter Bible). 
In fact, the proverb does not condemn gifts but rather points out their powerful ability for good. If a gift is given with good motives, it can be considered a sweet blessing. An example is God's gift of His only Son. It ensured eternal righteousness; motivated many people to love and serve Christ. The Armenian translation is somewhat closer to the original meaning of the proverb than the English one, even though it has more limited "proverbial" meaning. Consequently, taking into account the fact that people interpret the Bible differently it is preferable for the Armenian translator to render the Hebrew word "shachad" as "gift/present - uqunqu" for expressing its denotative meaning.

- "Like a gold ring or an ornament of gold is a wise rebuke to a listening ear." (Proverbs 25:12)

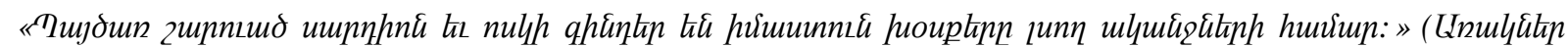
25:12)

The verse compares "gold ornaments" with "wise rebuke." The message is that heeding good rebuke or advice is rewarding. A person who is wise enough to accept the reproach isplays wisdom; the listening ear is ornamented with the "fine gold" of wisdom.

In the Armenian version a modulation ("gold ring" - uщujठun zunnıuд uupnhnd) is utilised to convey the same idea without altering the meaning of the proverb and without generating an unnatural feeling of reading a word-for-word translation. This change of perspective is accompanied by a lexical change in the target language: "gold" is replaced by another precious stone - "uupnhnu - carnelian."

It is of urgent necessity to mention that in the seventeenth century, an Armenian writer wrote that in India the lal or balas - ruby would dispel all dark emotions and create cheerful ones instead. The carnelian was powdered and drank in a potion for this purpose. Carnelian was also thought to provide the wearer with protection from any injury from falling houses or walls. This writer stated that "no man who wore a carnelian was ever found in a collapsed house or beneath a fallen wall" (Jewels For Me).

In Armenian a similar expression is used as a reproof to prevent someone from doing a mistake; to make someone or oneself understand something:

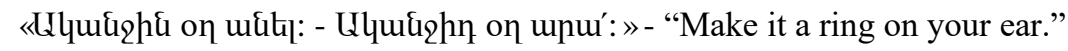

Both the form and the use of this Armenian phrase match well the biblical verse. It corresponds to the English expression "to get (something) through (someone's) thick head."

It should be noted that accepting wise advice in the Bible is valued in the same way as learning and gaining knowledge.

A good example of this statement is the first proverb of the book of Proverbs well known to Christian:

"For learning about wisdom and instruction, for understanding words of insight." (Proverbs 1:2)

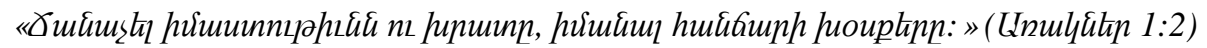

The folk counterparts of the proverb can be found both in English and Armenian:

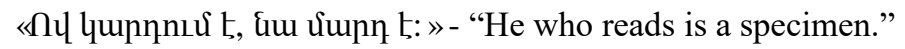

«nıunıún nult phцuqnıl t:» - "Education is a gold wristlet."

"The only jewel which will not decay is knowledge."

"Knowledge in every state is a grand treasure." (Fielding T., 1824: p. 65)

All these sayings are synonymous and can be considered adages.

- "Can Ethiopians change their skin or leopards their spots? Then also you can do good who are accustomed to do evil." (Jer 13:23)

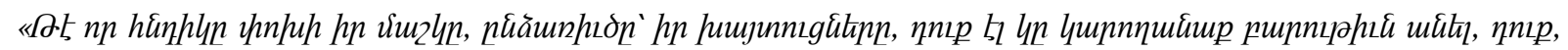

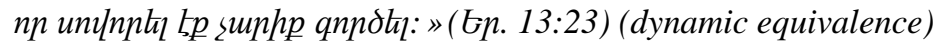

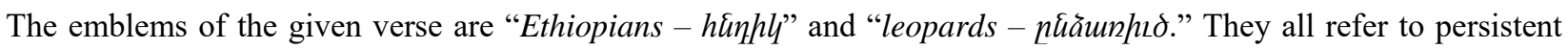
haughtiness unable to learn or change opinions, character/behaviour.

The word "Ethiopian" found in the English version is of abstract meaning and it is rendered in Armenian by the word "hinhll" determined by the context - both words are used in regard to human skin merely denoting a darker complexion. There are a few cases when Ethiopia is mentioned in Armenian ancient literature symbolising a remote and godforsaken place. 
The first line of the English version of the proverb is in interrogative form encapsulating "pseudo-assertion." Despite its interrogative form, it poses a question that is rather rhetorical in the sense it states a truth. This literary technique is an effective way to engage the reader and emphasize the point. The interrogative sentence, being omitted in the Armenian translation, is transformed into an adverbial clause of condition (pt np/tpht - if), expressing the circumstances/cases under which the action in the main clause may take place.

There are several Armenian proverbs similar to the given biblical passage in meaning but having different frames:

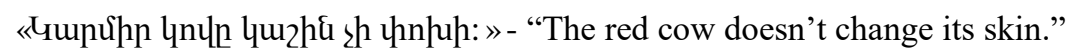

In Armenian, the cult of the cow (ox, bull) is explained by the humanitarian culture and livehood of indigenous inhabitants of the Armenian Highlands and the former totemic concepts. The "red cow" is a rarity in nature and hence it substitutes the English noun "leopard" for unleashing the cultural mentality of native speakers. Contrarily the complete equivalence of the biblical proverb is commonly used in the English-speaking world: "A leopard/tiger doesn't change its spots."

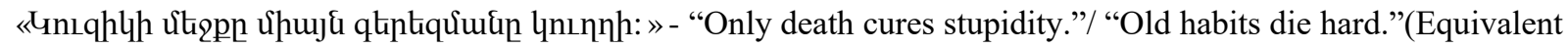
English proverbs)

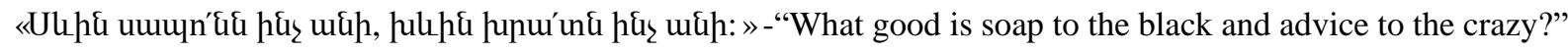

The substitution of the biblical "Ethiopians" with the word "black" in the Armenian proverb can be explained by the specific mentality which adds cultural vividness to the message of the contradiction "advising the insane."

\section{Conclusion}

Proverbs or proverbial sayings are multifaceted linguistic expressions in which form and meaning often intersect in complex ways. It is well-known that proverbs do not function as mere language items or a set of dogmas, but as norms and guidelines for securing a life of dignity and decency. Thus, they are one of the most difficult kinds of units to translate.

The Bible is not just a source of purely religious connotations, but also a piece of eminent literature that contains various types of figurative language, particularly parallelism. It may be inferred from the analysed data that the strategy of parallelism is well-applied in the book of Proverbs (both in English and Armenian) as it is a book explaining the consequences of actions and the sense of wisdom encoded in them.

Syntax is the way in which we can carve up sentences with needlework of parallel constructions. The ordering and paralleling of syntactic units are thoroughly observed in Hebrew poetic structures. Proverbs manifest these distinguished features that are often covered over in translation. Syntactic or structural parallelism is a rhetorical device used for the purpose of emphasis and accentuating. Several types of syntactic parallelism are frequent in proverbial statements:

Quite many parallel proverbial units of biblical origin differ in grammatical structure, or semantic characteristics, expressed in a familiar and an understandable pattern specific to national identity, the way of thinking, cultural norms and cultural assumptions. This is due to linguistic reasons (different language systems), and extralinguistic ones (intercultural differences).

Rendering the biblical proverbs, translators have applied a multitude of options available for translation, among which paraphrasing and various types of transformations predominate. However, any choice portrays the translator as an agent of modification and change.

\section{References}

Austin, J. L. (1975). How to do Things with Words, (2nd ed), J.O. Urmson and M. Sbisá (eds.), Cambridge, MA: Harvard University Press. https://doi.org/10.1093/acprof:oso/9780198245537.001.0001

Beardslee, W., Bird, P. H., \& others (1989). The New Revised Standard Version of the Bible, Anglicised (NRSVA), National Council of the Churches of Christ, USA.

Duckett, B. (2006). Oxford Dictionary of Phrase and Fable (2nd ed.). Oxford: Oxford Univesity Press.

Honeck, R. (1997) A Proverb In Mind: The Cognitive Science Of Proverbial Wit And Wisdom, USA: Lawrence Erlbaum.

Hornby, A. S., Wehmeier, S., \& Ashby, M. (2005). Oxford Advanced Learner's Dictionary of Current English (7th ed.). Oxford: Oxford University Press.

Linyan, F. (2017). On Semantic Equivalence in English-Chinese Translation. Advances in Social Science, 
Education and Humanities, Atlantis Press, Jiangxi Science \& Technology Normal University, 164-167.

Lowth, R. I. (1778). A New Translation; with a Preliminary Dissertation and Notes Critical, Philological, and Explanatory (Vol 2), London, 488.

Norrick, N. R. (1985). How Proverbs Mean? Semantic Studies In English Proverbs. Amsterdam: Mouton, 229. https://doi.org/10.1515/9783110881974

Vinay, J. P., \& Darbelnet, P. (1995). Comparative Stylistics of French and English: A methodology for translation. Amsterdam/Philadelphia: John Benjamins Publishing Company. https://doi.org/10.1075/btl.11

Zeytunyan, A., Sharabkhanyan, P., and others (1994). The Eastern Armenian New Translation (Untııłıuhujtiptu unp purquuuunıphı氏). The Holy See, Holy Etchmiadzin and The Armenian Bible Society.

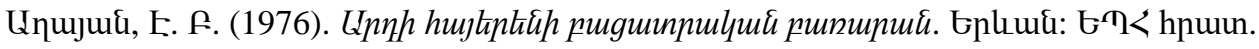

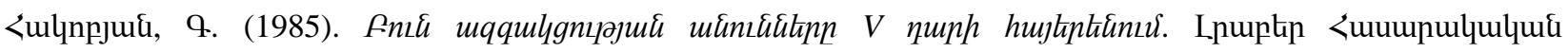

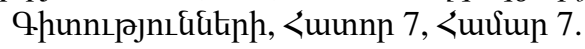

\section{Web Pages}

Abaddon. In Biblestudytools, Retrieved from https://www.biblestudytools.com/dictionary/abaddon/

Hakham. (2021). In Audioenglish, Retrieved from https://www.audioenglish.org/

Kesil. In Bible Hub, Retrieved from https://biblehub.com/hebrew/3684.htm

Sameach. In Biblestudytools, Retrieved from https://www.biblestudytools.com/lexicons/hebrew/nas/sameach.html

Shachad. In Blue Letter Bible https://www.blueletterbible.org/lang/lexicon/lexicon.cfm?t=esv\&strongs=h7810

Studfile (2015). Units Of Nationally Biased Lexicon And Ways Of Their Translation. Taras Shevchenko National University of Kyiv. Retrieved from https://studfile.net/preview/2267747/page:3/

The Talismanic Use of Special Stones (Agate - Diamond) (2021), in Jewels for Me, Retrieved from https://www.jewelsforme.com/gem_and_jewelry_library/curious_lore_chapter_three\#beryl

\section{Copyrights}

Copyright for this article is retained by the author(s), with first publication rights granted to the journal.

This is an open-access article distributed under the terms and conditions of the Creative Commons Attribution license (http://creativecommons.org/licenses/by/4.0/). 